\title{
EKLEKTISISME MAHDZAB (TALFIQ) DALAM PERSPEKTIF USHUL AL FIQH
}

\author{
Fathur Rahman Alfa, M.A \\ FAI UNISMA \\ e-mail: fathur.rahman.alfa@unisma.ac.id
}

\begin{abstract}
Abstrak
Ulama mutaakhirin menghukumi tidak diperbolehkannya beribadah yang "overlapping" dalam bingkai mahdzab, dengan berdasarkan berbagai hukum yang berbeda-beda diantara Imam Imam mahdzab. Tetapi seorang ahli ushul Fiqh asal Syiria, Wahbah Al Zuhaili mengatakan: bahwa batalnya talfiq secara mutlaq masih memerlukan argumentasi dan dalil yang kuat, karena bagaimanapun hal ini memerlukan perincian dan pengamatan yang cermat diantara sekian pendapat ulama antar mahdzab. Sehingga kepastian diperbolehkannya talfiq dalam bermadzhab menjadi objek kajian penelitian. Pendekatan yang digunakan dalam penelitian ini menggunakan pendekatan kualitatif. Pendekatan kualitatif denga jenis yang dipilih adalah studi pustaka (Library Research). Mengenai tatabbuu'r rukhash (mencari keringanan-keringanannya saja), ini dapat disimpulkan dalam beberapa pendapat: Pertama, fuqaha yang melarang orang mencari yang ringanringan saja dari berbagai mahdzab pada tiap-tiap masalah. Kedua beberapa ulama terdapat memperbolehkan talfiq harus berdasar udzur. Bila talfiq dilakukan oleh suatu negara dalam pembentukan suatu peraturan yang akan dijalankan umat islam, maka tidak ada alasan untuk menolaknya karena suatu Negara dalam berbuat untuk umatnya berdasarkan kemaslahatan umum.
\end{abstract}

Kata kunci: Eklektisisme Mahdzab (Talfiq, Perspektif, Ushul Al Fiqh.

\begin{abstract}
Ulema mutaakhirin punishes the prohibition of worship that is "overlapping" in the frame of mahdzab, based on various different laws between Imams and Imams. But a fiqh ushul expert from Syria, Wahbah Al Zuhaili said: that the nullification of talfiq mutlaq still requires strong arguments and arguments, because after all this requires a careful breakdown and observation among the various opinions among scholars. So that certainty is allowed talfiq in bermadzhab be the object of research studies. The approach used in this study uses a qualitative approach. The qualitative approach with the type chosen was library research (Library Research). Regarding tatabbuu'r rukhash (looking for relief only), this can be concluded in a number of opinions: First, fuqaha which prohibits people from looking for light
\end{abstract}

This work is licensed under Creative Commons Attribution Non Commercial 4.0 International License Available online on: http://riset.unisma.ac.id/index.php/fai/index 
things from various schools of thought on each issue. Secondly, there are some scholars who allow talfiq to be based on udzur. If talfiq is carried out by a country in the formation of a regulation that will be carried out by Muslims, then there is no reason to reject it because a State is acting for its people based on public benefit.

Keywords: Mahdzab Eclecticism (Talfiq), Perspective, of Usul Al Fiqh.

\section{A. Pendahuluan}

Perkembangan dan kemajuan yang terjadi di era sekarang membutuhkan kepastian hukum yang menjadi landasan seseorang dalam menjalankan sesuai syariah islam. Perbedaan kondisi turut mendorong dibutuhkannya kepastian hukum dalam beragama. Perbedaan lingkungan yang banyak dan rinci inilah menjadi alasan penting bagaimana solusi hukum sangat diperlukan oleh seseorang.

Fenomena taqlid yang terjadi setelah periode mujtahidin pada awal abad IV $\mathrm{H}$, yang masih berlangsung hingga saat ini, pada gilirannya melahirkan ketentuan yang diberikan para fuqoha mutaakhirin bahwa diperbolehkannya taqlid kepada mahdzab selain mahdzab imam yang diikutinya, tidak menjurus kepada ekleksi (talfiq) antar berbagai mahdzab. Ulama mutaakhirin juga menghukumi tidak diperbolehkannya beribadah yang "overlapping" dalam bingkai mahdzab, dengan berdasarkan berbagai hukum yang berbeda-beda diantara Imam Imam mahdzab. Bahkan sebagian ulama Hanafiah dan Syafiiyah mengatakan bahwa talfiq itu diperbolehkan secara ijma'.

Tetapi seorang ahli ushul Fiqh asal Syiria, Wahbah Al Zuhaili mengatakan: bahwa batalnya talfiq secara mutlaq masih memerlukan argumentasi dan dalil yang kuat, karena bagaimanapun hal ini memerlukan perincian dan pengamatan yang cermat diantara sekian pendapat ulama antar mahdzab. (Al Zuhaili. 1993: 56)

\section{B. Metode}

Pendekatan yang digunakan dalam penelitian ini menggunakan pendekatan kualitatif. Pendekatan kualitatif denga sifat yang dipilih adalah studi pustaka (Library Research). Penelitian ini sifatnya lebih ke arah metode kajian atas gagasan konseptual sedang data-data yang dikumpulkan dan yang akan dianalisis bertumpu pada ketersediaan sumber data di perpustakaan.

\section{Hasil dan Pembahasan}

Talfiq ialah merangkum beberapa hukum dengan suatu cara yang tidak difatwakan oleh seorang mujtahid, artinya ia menggabungkan beberapa hukum dari beberapa mahdzab dan beberapa pendapat yang berbeda mengenai suatu 
masalah, seperti seseorang berwudhu dan ia mengusap sebagian kecil dari kepalanya dengan mengikuti mahdzab syafi'i, lalu ia menyentuh wania tanpa adanyya unsur syahwat, dengan mengikuti mahdzab Hanafi, Maliki atau Hambali, dalam konteks tidak membatalkan wudhu, kemudian ia sholat, maka sholatna batal, karena wudhu yang dia laksanakan idak dibenarkan oleh imam mujtahid manapun; Syafi'i, menganggap batal karena menyentuh wanita (Ajnabiah), Abu Hanifah idak memperbolehkan karena tidak mengusap rambut sampai seperempat kepala demikian juga Ahmad bin Hambal tidak membenarkan karena tidak mengusap sebagian besar kepala.

Contoh talfiq yang dilarang dalam ahwal al-syahsiyah, seorang laki-laki kawin dengan wanita tanpa adanya wali, mahar dan saksi dengan mengambil setiap mahdzab serta menggabungkannya dan masing-masing tidak memberikan syarat yang sama, maka penggabungan seperi ini bisa membawa ke keadaan yang membahayakan dan meringankan agama dan tak seorang mujtahidpun menfatwakan seperti itu (Al Kamil, 1999:56). Selain itu, masih banyak contohcontoh lain.

Kuasa perasaan taklid yang mengharamkan pengikut dalam bermadzhab disinyalir menimbulkan talfiq pada seseorang. Hal tersebut ditanamkan kepada pengikut madzhab oleh ulama madzhab fikih. Talfiq ini tidak memperbolehakan seseorang bermadzhab tertentu mengambil pendapat madzhab lain. Tidak semuanya ahli fiqih menharamkan talfiq melainkan beberapa ulama baik hanafi maupun syafi'i.

Dalam pengamalan suatu pendapat fifkih sesseorang boleh melakukan talfiq ini menurut mayoritas ulama fiqh dan ushul fiqh. Beberapa ulama fikih maliki dan mayoritas ulama Syafi'i berpendapat bahwa talfiq tidak ditemukan larangan dalam satu nas (Al-Qur'an atau Hadist). Disamping itu, Rasulullah SAW memilih yang paling mudah bila dihadapkan denga dua pilihan yang dibenarkan agama.Allah Berfirman dalam Alquran surat al-Baqarah ayat 185 yang artinya: “...Allah tidak menghendaki kesukaran bagimu...” dalam ayat lain Allah SWT berfirman: “...dan Dia sekali-kali tidak menjadikan untuk kamu dalam agama suatu kesempitan..." (QS. 22:78)

Dalam memilih pendapat termudah dalam fikih tidak secara serta merta melainkan terdapat beberapa ketentuan:

1. Dalam memilih pilihan temudah harus ada sebab udzur dan tidak ada dorongan karena nafsu.

2. Keputusan hakim tidak bisa dibatalkan dengan talfiq"

3. Talfiq harus tetap mengesahkan suatu hukum atau amalan yang sudah diyakini (Al-Ghazali, tt: 230).

JAS: Volume 1 Nomor 2, 2019 
Dalam masalah akidah dan akhlaq talfiq tidak dibenarkan. Dalam hukum cabang yang dalilnya belum pasti tidak pasti dibidang fikih talfiq boleh dilakukan, ini menurut ulama fikih. Talfiq dalam masalah furu' tersebut dikategorikan menjadi tiga macam menurut ulama ushul fiqh;

1. Kemudahan dan kelapangan yang dapat berbeda dengan perbedaan kondisi setiap pribadi menjadi dasar ditetapkannya hukum. Hukum-hukum seperti ini adalah hukum yang termasuk al-ibadah al mahdah (ibadah khusus), karena dalam masalah ibadah khusus, tujuan yang ingin dicapai adalah kepatuhan dan loyalias seseorang kepada Allah SWT dengan menjalankan perintah-Nya. Dalam ibadah seperti ini factor kemudahan dan menghindarkan diri dari kesulian amat diperhatikan.

2. Sikap kewaspadaan yang penuh perhitungan menjadi dasar ditetapkan hukum. Hukum-hukum seperti ini biasanya berkaitan dengan sesuatu yang dilarang. Allah SWT tidak mungkin melarang sesuatu melainkan pada yang dilarang itu ada unsur mudharatnya. Dalam hukum-hukum seperti ini tidak dibenarkan kemudahan dan talfiq, kecuali dalam keadaan darurat. Misalnya, larangan memakan babi dan bangkai.

3. Kemaslahatan dan kebahagiaan bagi manusia menjadi inti dalam ketetapan hukum. Misalnya, Dalam pernikahan, tujuan yang hendak dicapai adalah kebahagiaan suami istri beserta keturunan mereka. Oleh sebab itu, segala cara yang dapat mencapai tujuan perkawinan tersebut boleh dilakukan, sekalipun terkadang harus dengan talfiq. Namun talfiq yang masih diambil tersebut tidak bertujuan untuk menghilangkan esensi pernikahan itu sendiri. Adapun dalam bidang muamalah dan pidana yang menjadi patokan adalah kemaslahatan pribadi dan masyarakat Berdasarkan kenyaaan diatas, ulama fiqih kontemporer menyattakan bahwa talfiq diperbolehkan, asal tidak menimbulkan sikap main-main dalam beragama atau mengambil pendapat tanpa alasan tertentu.

\section{Simpulan}

Penulis mengakhiri uraian ini dengan suatu masalah yang cukup peka dikalangan umat Islam, ialah masalah talfiq hukum yang hanya bertujuan tatabbuu'r rukhash, artinya mencampur aduk hukum dalam satu masalah dari berbagai mahdzab dan atau berbagai pendapat dari mujtahid/mufti, dengan maksud mencari keringanan-keringanannya saja. Mengenai tatabbuu'r rukhash (mencari keringanan-keringanannya saja), ini dapat disimpulkan dalam beberapa pendapat:

Pertama, fuqaha yang melarang orang mencari yang ringan-ringan saja dari berbagai mahdzab pada tiap-tiap masalah, antara lain al-Ghazali berkata: "Tidak boleh bagi orang awam memilih dari berbagai mahdzab pada tiap-tiap masalah JAS: Volume 1 Nomor 2, 2019 
yang dipandang berbagai/paling menyenangkan menurut dia kemudian dia memperluasnya". Ibnu Hazm sebagaimana dikutip oleh Jalaluddin al Mahali asySyafi'i didalam kitabnya syarah jam'u al jawimi', dan asy-Syatibi al Maliki didalam kitabnya al Muwafaqat menegaskan: "sesungguhnya telah ada ijma' untuk melarang mencari yang ringan-ringan saja dan sesungguhnya tindakan semacam itu tindakan fasik, tidak halal/boleh dilakukan". (AL-Subkhi TT dan Al-Syatibi, 1991: 350)

Ibnu Abdillah sebagaimana dikuttib oleh Ibnu Amir Al-Haj didalam kitabnya at-Taqwir wa att-ahbir mengatakan, bahwa "tidak boleh bagi orang awam mencari yang ringan-ringan, berdasarkan ijma'. Mencari yang ringan-ringan saja dan memilih pendapat-pendapat (dari para mujtahid) itu tidak lain adalah karena kecenderungan orang untuk memenuhi hawa nafsunya, padahal agama melarang mengikuti hawa nafsu. Dan mengikuti yang ringan-ringan saja dari berbagai mahdzab itu mengandung banyak mafsadat, antara lain ialah mempermainkan hukum agama dan melanggar hal-hal yang telah disepakati oleh para ulama". (Zuhdi, 1991:199)

Kedua, fuqaha yang membolehkan mengambil yang ringan-ringan dari berbagai mahdzab, antara lain ialah Al-Izz Ibnu Abdis Salam Al-Syafi'i didalam kitab Fatawi: "Bahwa umat Islam sejak sahabat sampai lahirnya mahdzabmahdzab selalu bertanya tentang berbagai masalah yang dihadapi kepada para ulama yang berbeda-beda pendapatnya. Dan mereka tidak mempersoalkan, apakah mereka mengambil hukum rukhshah (kelonggaran), atau mereka mengambil hukum-hukum 'Azimah (hukum asal). Sebab bagi orang yang mengangggap bahwa mujtahid yang benar hanya seorang, ia tidak menentukan siapa orangnya; dan bagi orang yang memandang mujahid yang benar lebih dari satu, maka tidak ada alasan untuk melarang mengikuti salah satu pendapat yang ada".

Bila talfiq dilakukan oleh suatu negara dalam pembentukan suau peraturan yyang akan dijalankan umattt islam, maka tidak ada alasan untuk menolaknya karena suatu Negara dalam berbuat untuk umatnya berdasarkan kemaslahatan umum. Umpamanya undang-undang perkawinan yang berlaku hamper di semua Negara yang berpenduduk muslim, dirumuskan atttas dasar talfiq.

Al-'Athar didalam hasyiyyahnya (komentar) atas Jam'ul Jamawi' mengatakan: "kesimpulannya, ialah boleh taqlid dan boleh mencari yang ringan-ringan, hanya tidak bebas; tetapi harus dijaga sampai dalam mengikuti yang ringan-ringan itu sampai jatuh mengenai hukum yang tersusun dari dua macam ijtihad". Demikian pula ada ad-Dasuqi al Maliki didalam kitabnya Hasyiyah'ala asy-Syarh al-Kabir menyimpulkan: "talfiq hukum dalam satu ibadah dari dua mahdzab itu dilarang menurut aliran ulama Mesir". (Zuhdi, 1991: 201)

JAS: Volume 1 Nomor 2, 2019 


\section{Daftar Rujukan}

Al-imam al Ghazali. 1991. Al Musthashfa min Ilm-al Ushul, Beirut: Dar Al-Fikr.

Al-Zuhaili, Wahbah. 1993. Al Ruhshah Al Syariyyah, AhKamuha wa Dhawabitha. Damaskus: Dar Al-Khair.

Al-Kamil, Muhammad Abdullah. 1999. Al Ruhshah Al Syariyyah, fi Al-Qawa'id wa AlUshul Al-Fiqhiyyah. Kairo: Dar Ibn Hazm.

Al Syyattibi. tt. Al-Muwafaqat. Beirut: Dar Al-Fikr.

Al-Subkhi, Tajuddin. Tt. Jam'u Al Jawami'. Beirut: Dar Al-Fikr.

Zuhdi, Masyfu', 1991. Pengantar Hukum Islam. Jakarta: Mas Agung.

JAS: Volume 1 Nomor 2, 2019 